\title{
Förändringar av Sveriges underrätter efter år 1900
}

\section{Av Erik Wångmar}

\author{
Länk till presentation av Erik Wångmar
}

- Organisationen vid 1900-talets början

- Förändringar 1901-1970

- Omdaningen 1971

- Förändringar 1971-1999

- Förändringar sedan 1999

- Sammanfattande analys

För närvarande pågår en omfattande förändring av landets tingsrättsorganisation. Kanske lite förvånande har denna omdaning inte väckt särskilt stor uppmärksamhet på nationell nivå. Det har visserligen skett en del protester på de orter som har berörts av nedläggningarna, men inte heller dessa har varit så väldigt utbredda eller högljudda. Mot bakgrund av denna förändringsprocess anser jag att det finns ett behov att göra en historisk tillbakablick över hur lokaliseringen av de svenska domstolarna i första instans (underrätterna) har förändrats under de senaste 100 åren. Syftet med artikeln är framförallt att ge ett historiskt perspektiv på en aktuell samhällsfråga och även relatera denna till andra liknande centraliseringsprocesser inom den offentliga verksamheten, inte minst inom andra delar av rättsväsendet såsom polisen.

\section{Organisationen vid 1900-talets början}

Vid 1900-talets början var Sverige ett land i stark förändring. Industrisektorn växte i snabb takt, medan jordbrukets betydelse minskade. Ännu år 1900 var 55 procent av befolkningen knuten till jordbruket, medan industrins och hantverkets andel uppgick till 28 procent. Detta betydde att landsbygdsbefolkningen fortfarande var i klar majoritet. År 1901 fanns det 92 städer. I dessa var 22 procent av befolkningen bosatt, medan nio procent bodde i andra tätorter. Den rena landsbygdsbefolkningen uppgick alltså till 69 procent.[1]

Det var sålunda mot bakgrund av dessa samhällsförhållanden som landets underrätter var organiserade vid sekelskiftet. Under 1800-talet hade nästan alla nya städer fått en egen domstol i form av en rådhusrätt. Bland domsagorna på landsbygden hade det skett en hel del förändringar under samma sekel. Dessa hade medfört en viss ökning av antalet domsagor, särskilt i länen i Norrland. År 1901 fanns det 90 rådhusrätter och 118 domsagor (häradsrätter), alltså sammanlagt 208 underrätter. Som namnet angav bestod häradsrätternas geografiska område av ett eller flera olika härad (i Norrland tingslag). Chefen för rådhusrätten titulerades borgmästare, medan chefsdomaren i domsagan kallades häradshövding. Åtskillnaden mellan stad och land i fråga om domstolarna återfinns i rättskällor från 1200-talet. Indelningen innebar att alla städer utom två, Borgholm och Haparanda, hade en egen domstol. Det skall särskilt noteras att en hel del städer utöver de två ovannämnda då hade få invånare. Genom att det stora flertalet av domsagorna var uppdelade på flera tingslag med tillhörande tingsställen var den dömande funktionen på Sveriges landsbygd relativt decentraliserad, särskilt i landets mellersta och södra delar. Tingslagen sågs i formellt avseende som en domsaga, men som två eller flera häradsrätter med en gemensam häradshövding. I de nordligaste länen var det glest mellan domsagorna. I det till ytan synnerligen stora Norrbottens län fanns det exempelvis år 1901 bara fyra domsagor. Östergötlands län, som till ytan var avsevärt mindre, hade däremot hela åtta 
domsagor. I fem andra län, Malmöhus, Älvsborg, Skaraborg, Värmland och Västernorrland, fanns sju domsagor. Den länsvisa fördelningen baserades alltså i större utsträckning på folkmängd än på geografiska förhållanden.[2]

\section{Förändringar 1901-1970}

Under perioden fram till 1970 gällde flertalet förändringar rådhusrätterna. Mellan 1901 och 1951 ökade antalet städer från 92 till 133. Därefter tillkom inga nya städer De nytillkomna städerna lades efter 1901 utan undantag under en domsaga på landet. Detta gjorde att antalet rådhusrätter inte ökade. Fram till i början på 1930-talet var det enbart några få rådhusrätter i småstäder som avvecklades. Under andra halvan av 1930-talet och under 1940-talet tog denna process på allvar fart. Detta var framförallt ett resultat av att riksdagen 1932 hade antagit en lag som gjorde det möjligt för regeringen att lägga städer under domsagor trots att staden motsatte sig detta. För städerna innebar visserligen rådhusrätten en extra kostnad, men samtidigt sågs den som en statusfråga, varför städerna inte alltid godvilligt ville läggas under en domsaga. Mellan 1935 och 1951 minskade antalet städer med egen domstol från 86 till 48. Det viktigaste enskilda tillfället var 1948 då den nya rättegångsbalken trädde i kraft. Mellan 1947 och 1948 minskade antalet rådhusrätter från 64 till 51. Till största delen gällde detta städer med liten folkmängd. Rådhusrätterna behölls sålunda i residensstäderna och i ett antal andra medelstora och större städer.

Minskningen av antalet städer med rådhusrätt fortsatte i mer långsam takt under 1950- och 1960-talen. 1961 fanns det 41 rådhusrätter och 1970 var de 27. Vid den senare tidpunkten var det företrädesvis residensstäderna som hade kvar rådhusrätten. Riktmärket var att det skulle finnas underlag för tre ordinarie domare (borgmästare och rådmän) för att städer skulle utgöra en egen domkrets. Att flertalet städer lades under en domsaga innebar oftast inte några större geografiska olägenheter, detta då flertalet domsagor med tillhörande tingsställen var belägna i städer eller i städernas närhet. Att staden lades under en domsaga innebar att staten fick ansvaret för finansieringen av domstolens verksamhet.[3] Minskningen av antalet rådhusrätter under 1960-talet var delvis ett resultat av den statliga utredning om städernas domstolar som hade lämnat ett principbetänkande 1961. Enligt detta var det lämpligt att minska antalet rådhusrätter från 41 till 18. Rådhusrätterna skulle alltså bara behållas i de största städerna.[4]

1965 förstatligades de kvarvarande rådhusrätterna. Detta skedde samtidigt som hela polisväsendet förstatligades och omorganiserades. Tidigare hade det bara funnits en begränsad statspolis för speciella uppgifter såsom säkerhetstjänst, trafikövervakning och förstärkning. Detta förstatligande var jämte införandet av den enhetliga underrättsorganisationen 1971 de största förändringarna av det samlade svenska rättsväsendet i modern tid. Att polisen förstatligades innebar en mycket större enhetlighet av polisens organisation och materiella standard. Kommunernas befattning med rättsväsendet blev därefter mycket begränsad och inskränktes närmast till att välja nämndemän. En annan viktig förändring var införandet av den nya rättegångsbalken 1948 . Denna innebar bl.a. att den nuvarande organisationen med sex hovrätter infördes och att systemet med nämndemän även började användas i rådhusrätterna. Sammantaget medförde denna reformering att skillnaden mellan rättsskipningen i städerna och på landsbygden blev mindre.[5] Detta var ett steg på väg mot en fullständig harmonisering mellan rättsväsendet i stad och land som trädde i kraft år 1971, vilken berörs närmare nedan.

Förändringen av antalet domsagor var under perioden 1901-1970 tämligen liten. Fram till början av 1960-talet tillkom nio nya domsagor i företrädesvis landets nordliga delar och i Stockholms län. I båda fallen berodde detta främst på en stor ökning av folkmängden. I norr spelade dock också de geografiska förhållandena in. Toppen nåddes 1921 med 125 domsagor. Under samma period försvann nio domsagor i södra och mellersta Sverige. Det gällde framförallt domsagor med liten och stagnerande folkmängd. År 1961 fanns det alltså lika många domsagor som 1901. Under 1960-talet skedde det däremot något större 
omdaningar. Genom dessa minskade antalet domsagor till 108 år 1970. Det gällde även denna gång främst domsagor i södra och mellersta Sverige med ganska låg folkmängd. I vissa fall handlade det i praktiken om förtida genomföranden av 1971 års reform.

Antalet domsagor som var uppdelade på flera olika tingslag minskade gradvis. Processen var särskilt tydlig i början av seklet och inte minst i samband med att den nya rättegångsbalken trädde i kraft 1948. Efter 1948 var det bara ett klart begränsat antal domsagor, företrädesvis i Norrland, som var uppdelade på flera tingslag. Däremot var det fortfarande förhållandevis vanligt att domsagorna hade flera tingsställen. Det gamla relativt nära sambandet mellan tingslag och tingsställe fanns alltså inte längre.[6]

\section{Omdaningen 1971}

Utredningen om domstolarna i städerna, som lämnade sitt betänkande 1961, var ett steg i riktning mot en full harmonisering av underrätterna i städerna och på landet. I denna utredning påtalades det att redan 1926 hade en statlig kommitté föreslagit att domstolarna i städerna och på landsbygden till stor del skulle jämställas. Bara ett fåtal rådhusrätter skulle behållas och domsagorna skulle göras betydligt större. 1960-talets process gick vidare genom att regeringen på våren 1961 tillsatte en domstolskommitté. Kommittén föreslog i ett första betänkande 1963 att rådhusrätterna skulle förstatligas, vilket också skedde 1965. I fråga om domsagornas storlek borde dessa normalt ge underlag för tre domartjänster. Vidare borde antalet orter som hade flera underrätter klart begränsas. Kommittén föreslog sedan 1967 att landet i framtiden skulle vara indelat i totalt 86 underrätter. 1966 fanns det 148 rådhusrätter och domsagor. Reduceringen skulle därmed uppgå till 42 procent. Principen var, liksom 1963, att nästan alla domstolar skulle ha underlag för minst tre domartjänster. I ett mindre antal fall föreslogs domstolar med bara två domare. Den gamla ordningen med domsagor som bara hade en häradshövding som ordinarie domare skulle däremot helt upphöra. Det var också viktigt att de pågående kommunsammanläggningarna beaktades fullt ut när den nya indelningen i domkretsar gjordes upp.[7]

Reformens omfattning skulle variera förhållandevis mycket mellan de olika länen. I Kronobergs län skulle antalet underrätter minskas från fem till två. Även i grannlänet Kalmar skulle förändringen bli stor, då antalet domstolar skulle minska från sju till tre. I Gotlands län skulle det däremot inte ske någon förändring alls. I Norrbottens län föreslogs en minskning från sex till fem domstolar. Det skall betonas att i en hel del fall handlade det om att slå samman domstolar som hade kansli och tingsställe i samma stad. Detta gällde inte minst de städer som fortfarande hade rådhusrätt. Den geografiska tillgängligheten skulle därför knappast alls påverkas. Förändringen kunde därför ses som en rationell åtgärd som innebar en kostnadsreducering utan större negativa effekter. Situationen i Kronobergs län ger en god illustration av detta. Av länets fem domstolar hade tre kansli och tingsställe i Växjö. Dessutom fanns det en domstol med kansli och tingsställe i Alvesta, mindre än två mil från Växjö.[8]

Våren 1969 lämnade regeringen en proposition till riksdagen med förslag till en enhetlig underrättsorganisation. Samtliga domstolar skulle benämnas tingsrätt och chefsdomaren skulle tituleras lagman. Helst skulle domkretsarna ge underlag för minst tre domare. Det skulle dock finnas möjligheter att ha domsagor med bara två domare. Detta skulle ske när det fanns särskilda lokala orsaker, inte minst på geografisk grund. Vid indelningen i domkretsar skulle kommunerna vara byggstenar. Indelningen skulle alltså inte få skära kommungränser. Den nya indelningen skulle genomföras gradvis och i stort sett vara genomförd år 1975. Det enhetliga systemet med bara en typ av underrätt skulle dock träda i kraft redan den 1 januari 1971.[9]

Riksdagsbehandlingen innebar inga avgörande förändringar i förhållande till propositionen, dock skedde smärre revideringar av riktpunkten för domkretsarnas storlek. Vissa borgerliga riksdagsledamöter och någon enstaka socialdemokrat hade nämligen i motioner föreslagit att utgångspunkten skulle vara att domstolarna hade minst två domare eller att den nuvarande domkretsindelningen i stort sett skulle behållas. Riksdagen intog en lite mer 
generös linje till att ha domkretsar med bara två domare än vad regeringen hade gjort. De borgerliga motionerna hade sålunda viss framgång vid riksdagsbehandlingen.[10] Denna kompromiss i riksdagen medverkade till att göra 1971 års reform mindre långtgående än vad den socialdemokratiska regeringen egentligen hade önskat. I praktiken hade detta betydelse för omfattningen av dagens förändringar av tingsrätterna.

Under åren 1969-1970 beslöt regeringen om förändringarna av den nya indelningen i domsagor. Merparten av nyordningen skulle träda i kraft 1971, medan andra beslut skulle träda i kraft vid senare datum. När alla rådhusrätter och häradsrätter blev tingsrätter 1971 fanns det 108 sådana domstolar. 1970 hade det funnits totalt 135 domstolar. I några fall fanns det fortfarande kvar flera domstolar i en och samma stad. Flertalet av dessa tillhörde de domstolar som skulle avvecklas fram till mitten av 1970-talet. Det skall vidare framhållas att en del tingsställen drogs in i samband med detta, vilket negativt påverkade den geografiska tillgängligheten till domstolarna. I Kronobergs län genomfördes den förändring som hade föreslagits redan 1967, vilken alltså innebar att antalet domstolar minskade från fem till två.[11]

Med tanke på att domsagoindelningen till stor del hade varit oförändrad under hela 1900talet måste indragningarna av domstolar betecknas som mycket måttfull. Minskningen innebar inte så mycket, då det i en hel del fall gällde en samordning av domstolar som låg på samma ort. Att regering och riksdag gick försiktigt fram innebar en viss kontrast till vad som hände i fråga om den kommunala indelningen, där den socialdemokratiska regeringen intog en betydligt hårdare linje för att slutföra kommunblocksreformen senast 1974. Det skall erinras om att vid årsskiftet 1970/1971 skedde två andra betydelsefulla förändringar i syfte att skapa större enhetlighet. Det gällde dels införandet av enkammarriksdagen som var direkt folkvald, dels tillkomsten av den enhetliga kommunbeteckningen. Att städer, köpingar och landskommuner nu samtliga benämndes kommuner hade också en klar koppling till införandet av enhetliga domstolar i första instans. När det inte längre fanns några städer i administrativ mening kunde det inte heller finnas några specialdomstolar för städerna. Dessutom innebar kommunblocksreformens sammanläggningar, vilka skedde i stor omfattning just vid årsskiftet 1970/1971, att städerna med rådhusrätt lades samman med omkringliggande landsbygd.[12] Uppdelningen mellan stad och land i fråga om rättsväsendet hade därmed slutligen suddats ut i formella sammanhang efter nästan 800 år.

\section{Förändringar 1971-1999}

De fortsatta förändringarna innebar att det 1974 fanns 101 tingsrätter. Enligt regeringens beslut skulle ytterligare indragningar ske fram till 1977. Flertalet av dessa kom dock aldrig att verkställas.[13] Detta berodde sannolikt på att den socialdemokratiska regeringen tog visst intryck av de lokala opinionerna på de berörda orterna. Efter den borgerliga regeringens tillträde 1976 blev det ännu mer uppenbart att det inte skulle ske några större indragningar av tingsrätter. Istället skedde det en form av decentralisering genom att tingsrätter i Stockholms och Uppsala län, som hade Stockholm och Uppsala som kansliorter, utlokaliserades till orter som var belägna i domkretsen. I samband med detta tillkom även en ny tingsrätt i Stockholms län. Efter 1980 kvarstod bara tre tingsrätter, numera två, som hade kansli och tingsställe utanför den egna domkretsen.

Att en del mindre domstolar blev kvar innebar att det förekom tingsrätter som bara hade en ordinarie domare (lagman). Denna organisation stämde alltså överens med hur det såg ut i en del domsagor fram till 1970. Enligt 1969 års riksdagsbeslut skulle en sådan ordning i princip inte förekomma. Flera domstolar som enligt domstolskommittén redan år 1967 var alltför små för att behållas har funnits kvar in på 2000-talet. En annan effekt av att reformen inte fullföljdes var att indelningen inte blev konsekvent i de olika länen. I Blekinge län, som hade både en liten yta och folkmängd, fanns det fortfarande 1999 fyra tingsrätter. I Västerbottens och Kalmar län, vilka båda hade betydligt större areal och folkmängd, fanns det däremot bara tre tingsrätter. Att ha fyra domstolar i ett län som består av endast fem kommuner kan tyckas vara klart överdimensionerat. Det kan vidare noteras 
att utifrån de geografiska förhållandena var de båda länen i Skåne också väl tillgodosedda med tingsrätter. Detta hängde bland annat samman med att indelningen i domsagor följde länsgränserna. Genom bildandet av Skåne län 1997 ändrades förutsättningarna för att slå samman tingsrätter i detta område.

Mellan 1974 och 1999 minskade antalet tingsrätter från 101 till 97. Huvudsakligen handlade det om sammanslagningar av domstolar som hade säte i samma ort.[14] Dessa förändringar hade alltså ingen egentlig betydelse för allmänhetens tillgänglighet till domstolarna. Sammanfattningsvis innebar senare delen av 1970-talet samt 1980- och 1990talen en stabilitet i den yttre organisationen för landets underrätter.

\section{Förändringar sedan 1999}

Det första steget till en större omstrukturering av tingsrätterna togs av regeringen redan år 1989, då det tillsattes en parlamentarisk domstolsutredning som skulle arbeta i samarbete med statskontoret. Statskontoret föreslog att antalet tingsrätter skulle reduceras till omkring 30. De övriga nuvarande tingsrätterna skulle bli lokala enheter underordnade de nya tingsrätterna. Detta förslag avfördes genom att regeringen återkallade utredningsuppdraget. Istället skedde det en översyn internt inom justitiedepartementet. I denna framkom tre olika alternativ. Det första innebar att varje tingsrätt skulle ha minst tre domare, vilket skulle medföra nedläggningar av 24 tingsrätter och därmed skulle 73 vara kvar. Enligt det andra alternativet skulle alla tingsrätter ha minst fyra domare. Om detta genomfördes skulle 43 tingsrätter försvinna och 54 kvarstå. Det tredje alternativet föreskrev en indelning där sju domare var ett minimikrav. Detta skulle leda till nedläggning av 53 tingsrätter. Det skulle alltså bara bli 44 tingsrätter kvar. Enligt utredarna fanns det goda skäl att välja alternativ ett. Vidare skulle de mindre tingsrätterna få administrativt stöd av hovrätterna. De tingsrätter som inte uppfyllde minikraven skulle ersättas av tingsställen. Även Statskontorets modell om samordning inom länen redovisades. Det som särskilt skall noteras var att många av de nedläggningar av tingsrätter som har skett sedan 1999 fanns med som tänkbara förslag i modellerna med minst fem respektive sju domare i varje tingsrätt. Vid remissbehandlingen fick förslaget om att ha minst tre domare ett ganska starkt stöd. Motståndet kom främst från de tingsrätter som riskerade att läggas ned, vilka framförde olika sakskäl till att just den egna domstolen borde få kvarstå. Därefter redovisade den borgerliga regeringen frågan för riksdagen, som fann att det då saknades skäl till att ändra tingsrättsindelningen.[15]

År 1995 initierade den socialdemokratiska regeringen en ny utredning av landets domstolar. Ett syfte med utredningen var att åstadkomma besparingar. Innan något förslag lades fram upprepades historien från 1991, då regeringen 1998 återkallade uppdraget i denna del. Detta hängde inte minst samman med att kommittén hade meddelat att det inte gick att komma överens om en långtgående reformering av tingsrättsorganisation, som innebar nedläggning av ett stort antal domstolar. Arbetsmaterialet redovisades dock. Av detta framgick det att många av de senaste årens nedläggningar av tingsrätter fanns med som alternativ i utredningens diskussioner. Det redovisades två organisationsalternativ. Enligt det första skulle antalet tingsrätter reduceras till 43, medan det andra alternativet byggde på att det skulle finnas 64 tingsrätter i framtiden. Vidare behandlades det nätverksalternativ där mindre tingsrätter skulle vara underordnade större tingsrätter samt ett närmare samarbete mellan allmänna domstolar (tingsrätter) och förvaltningsdomstolar (länsrätter). Regeringen ansåg trots allt att reformeringen skulle fortsätta, men med andra utredningsmetoder.[16]

Det fortsatta reformarbetet bedrevs istället av Justitiedepartementet och Domstolsverket. I april 2000 överlämnade regeringen en handlingsplan till riksdagen om hur förändringarna skulle gå till. Då hade redan en tingsrätt lagts ner som ett led i omstruktureringen. Det fanns ett flertal motiv till att domkretsindelningen skulle revideras. Det gällde bland annat behovet av en ordentlig beredningsorganisation i varje domstol, behovet av kompetensutveckling, domstolarnas tekniska utveckling samt förutsättningarna för 
samverkan mellan domstolarna och övriga delar av rättsväsendet. Det framhölls att medborgarnas krav på geografisk tillgänglighet till domstolarna skulle beaktas. Förändringen av underrätterna kunde ske på tre olika sätt, nämligen att tingsrätter slogs samman, att domstolar samarbetar i gemensamma domkretsar samt att befintliga domstolar ersätts av tingsställen. Utredningsarbetet skulle utföras av Domstolsverket och i regel ske region för region. I skrivelsen lämnades även konkreta förslag på nedläggningar av tingsrätter. Utöver den nedläggning som hade skett 1999 och en nedläggning som skulle ske sommaren 2000 föreslogs ytterligare nio tingsrätter försvinna. Fyra av dessa skulle dock bli kvar som filialkanslier inom ramen för gemensamma domkretsar.[17]

Riksdagsmajoriteten bestående av socialdemokraterna, vänsterpartiet och miljöpartiet ställde sig bakom regeringens handlingsplan. Detta innebar alltså att regeringen fick klartecken att gå vidare med förändringen, och i enlighet med gällande lagstiftning, rättegångsbalken, på egen hand fatta beslut om sammanläggningar av domkretsar. De fyra borgerliga partierna reserverade sig däremot till förmån för att riksdagen skulle fatta alla beslut om ändringar av indelningen i domkretsar.[18]

I mars 2001 återkom regeringen med en ny skrivelse till riksdagen om den forstsatta reformeringen av landets tingsrätter. I denna noterades att riksdagen vid budgetbehandlingen för 2001 beslutat om att lägga ner ytterligare sju tingsrätter. En av dessa skulle kvarstå som filialkansli. I skrivelsen lämnades förslag på att ta bort sex tingsrätter till, av vilka två skulle få bestå som filialkansli. Det fortsatta reformarbetet skulle särskilt riktas in på tingsrätternas organisation i storstadsområdena. Regeringen ville alltså på nytt ha klartecken av riksdagen att gå vidare i processen.[19]

Vid riksdagsbehandlingen ställde sig socialdemokraterna, vänsterpartiet och miljöpartiet bakom regeringens skrivelse. Kristdemokraterna, centern och folkpartiet upprepade kravet från år 2000 om att riksdagen borde fatta de formella besluten om domkretsindelningen. Dessutom ansågs medborgarperspektivet i fråga om den geografiska tillgängligheten till domstolarna ha fått alltför litet utrymme. De tre partiernas krav på en oberoende utvärdering av förändringarna och att inga ytterligare sammanläggningar skulle göras i avvaktan på utvärderingen, stöddes även av moderaterna.[20]

I maj 2002 tillsatte regeringen en utredning som skulle utvärdera de ändringar av tingsrättsorganisationen som skett under åren 1999-2001. Det handlade om en ensamutredare som i slutskedet hade en parlamentarisk referensgrupp till sin hjälp. Utredningen, som var färdig i januari 2003, kom fram till att sammanläggningarna av tingsrätter hade inneburit ett antal positiva effekter. En del i detta var betydande ekonomiska besparingar utan större negativa effekter för domstolarnas verksamhet. Den befarade försämringen av allmänhetens geografiska tillgänglighet till domstolarna hade inte blivit särskilt stor. Flertalet medborgare kom dessutom sällan eller aldrig i direkt kontakt med tingsrätterna. Däremot innebar det vissa negativa effekter i form av återkommande längre resor för nämndemännen. De positiva effekterna gällde en bättre beredningsorganisation, ökad kompetensutveckling och bättre samordning med andra myndigheter inom rättsväsendet såsom kriminalvården, åklagarna och polisen. Däremot hade det inte skett några större förändringar i fråga om rekrytering och specialisering. I det senare fallet var detta svårt att uppnå utanför de största tingsrätterna. Utredaren ansåg att det var nödvändigt att gå vidare med reformeringen. Ett viktigt skäl till detta var att många små tingsrätter var alltför sårbara personellt för att kunna existera i framtiden. Modellen med flera kansliorter inom en domkrets borde undvikas. Istället borde endast tingsställen inrättas.[21]

I maj 2003 kom regeringen med en ny skrivelse med förslag till fler sammanläggningar av tingsrätter. Utifrån den ovannämnda positiva utvärderingen fanns det skäl att gå vidare. Mellan 1999 och 2003 hade antalet tingsrätter minskat från 96 till 72. I skrivelsen fanns bara fyra regelrätta förslag på nedläggningar av tingsrätter. Därutöver diskuterades ett flertal olika alternativ till förändringar.[22] Budgetpropositionen för 2004, som lämnades i september 2003, innehöll fler förslag på nedläggningar. Det gällde då avveckling av 
ytterligare sju tingsrätter. När dessa var genomförda skulle det alltså finnas 61 tingsrätter kvar. Det skall dock betonas att reformarbetet skulle fortsätta, varför ytterligare nedläggningar kommer att ske i framtiden.[23]

När riksdagen behandlade frågan på hösten 2003 fick regeringens förslag stöd från socialdemokraterna, vänsterpartiet och miljöpartiet. Regeringen fick alltså mandat att gå vidare med att slå samman tingsrätter. Samtliga borgerliga partier lämnade reservationer på olika punkter. I en gemensam reservation framfördes krav på en bredare konsekvensanalys för de orter som hade berörts av förändringarna. Medborgarperspektivet borde ha högre prioritet än kostnadsaspekterna. Innan en sådan analys var gjord borde inga fler sammanläggningar ske. Kristdemokraterna och centern ville även att riksdagen skulle besluta om alla förändringar av domkretsindelningen.[24]

Under perioden 1999-2003 har det alltså gjorts långt fler nedläggningar av tingsrätter än vad som skedde åren 1971-1999. Dessutom kommer utvecklingen att fortsätta i samma riktning i framtiden. I procentuella tal var minskningen 1999-2003 visserligen mindre än den som skedde under den förra större omdaningsperioden 1961-1974. I praktiken var dock dessa förändringar mindre långtgående eftersom det till ganska stor del handlade att lägga samman domstolar som hade kansli i samma ort. De geografiska avstånden till domstolarna har alltså påverkats i större utsträckning vid de senaste årens sammanläggningar. Om regering och riksdag fullföljer denna linje, vilket får anses högst troligt, är det tänkbart att landet om några år bara har mellan 30 och 40 tingsrätter kvar. I vissa län finns redan i nuläget endast en tingsrätt. Med stor sannolikhet kommer en sådan ordning att införas i fler län inom en ganska snar framtid.

\section{Sammanfattande analys}

Landets underrätter har under de senaste 100 åren genomgått ganska stora förändringar. Dessa skall självklart ses mot bakgrund av mer övergripande samhällsförändringar såsom industrialiseringen, urbaniseringen och utbyggnaden av välfärdssamhället. Vidare har brottsligheten ökat och även blivit långt grövre under framförallt perioden 1950-1990. Ökningen har särskilt gällt egendomsbrott, ekonomiska brott och våldsbrott. I ett europeiskt perspektiv har utvecklingen varit ganska normal. En effekt av den ökade brottsligheten har varit att brott av lindrig karaktär bara behandlas av polis och åklagare. Ärendena förs därmed inte till domstolarna. I annat fall hade domstolarnas arbetsbelastning blivit mycket stor.[25] Den principiellt viktigaste förändringen av underrätterna var 1971 års reform som jämställde alla landets allmänna domstolar i första instans. Den 800 år gamla uppdelningen mellan rådhusrätter i städerna och häradsrätter på landsbygden ersattes då med tingsrätter. Mellan år 1900 och mitten av 1930-talet var förändringarna av underrätterna små. Det mest intressanta med utvecklingen under perioden var att efter 1901 låg alla nytillkomna städer kvar under den domsaga som orten hade tillhört innan stadsbildningen. Genom detta ökade inte antalet rådhusrätter trots en klar ökning av antalet städer. Från mitten av 1930-talet avvecklades alltfler rådhusrätter. Med få undantag gällde det städer med liten folkmängd. Processen var särskilt intensiv under 1940-talet i anslutning till den nya rättegångsbalkens införande 1948. Under 1950- och 1960talen fortsatte utvecklingen, men i lugnare tempo. Vid införandet av de enhetliga underrätterna 1971 fanns rådhusrätterna främst kvar i residensstäderna och ett antal andra större städer. Antalet domsagor var under perioden 1900-1970 ganska stabilt. Det var först under slutet av 1960-talet som en smärre minskning ägde rum. Det handlade då delvis om förtida genomföranden av 1971 års reform. Vid denna tidpunkt hade det totala antalet underrätter ungefär halverats i förhållande till situationen år 1900.

1971 års reform urgröptes dessutom på två olika sätt. För det första gjorde riksdagen 1969 reformeringen mindre långtgående än vad regeringen hade föreslagit i propositionen. Detta skedde genom att möjliggöra fler domstolar med bara två domare. Socialdemokraterna gick alltså de borgerliga till mötes för att skapa enighet i frågan. För det andra genomförde inte regeringen alla de nedläggningar av tingsrätter som hade beslutats 1969-1970. Dessa 
reträtter hängde både samman med aktiviteter i riksdagen från framförallt borgerligt håll och med lokala protester från de berörda orterna. Dessa båda omständigheter har självklart medverkat till att behovet av förändringar av tingsrätterna blev ännu större när frågan på allvar åter kom upp på den politiska dagordningen under 1990-talet. Ett mått på detta var att domstolskommittén år 1967 hade föreslagit att det i mitten av 1970-talet skulle finnas 86 tingsrätter. Ännu i början av år 1999 fanns det emellertid 96 tingsrätter kvar.

Genom att förändringarna i viss mån dels hade gällt att lägga samman rådhusrätter med domsagor på samma ort, dels att sammanslå domsagor som hade säte på samma plats, var förändringarna ur ett geografiskt perspektiv förhållandevis måttfulla. Det gällde alltså inte minst en centraliserings- och koncentrationsprocess till färre enheter. Den geografiska centraliseringen var däremot inte lika omfattande. Ur ett geografiskt perspektiv hade inte allmänhetens tillgänglighet till underrätterna försämrats på något långtgående sätt. Detta är ett viktigt konstaterande som står i viss kontrast till de förändringar av domstolarna som pågår i nuläget.

Fram till mitten av 1970-talet skedde sedan ett antal ytterligare nedläggningar. Detta hängde samman med att 1971 års reform inte skedde på en gång, utan skulle vara fullt genomförd först i mitten av 1970-talet. Under de följande 25 åren var ändringarna av underrätternas yttre organisation mycket små. Från politiskt håll fanns det länge uppenbarligen en rädsla för att göra större reformeringar av domstolarna. Frågan var helt enkelt politiskt känslig. Denna hållning ändrades först under slutet av 1990-talet. I de utredningar som förekom under 1990-talet diskuterades till stor del de förändringar som har kommit till stånd sedan 1999. Kanske behövdes det en viss mental omställningsperiod innan tiden var inne för att gå vidare. Vidare får det anses högst troligt att arbetet har varit klart effektivare när det har utförts av Domstolsverket än i en parlamentarisk utredning, där politiska avvägningar och hänsynstagande till hemmaopinioner lätt kan slå igenom.

Från 1999 och framåt har processen gått mycket snabbt och kommer med största sannolikhet att fortgå så under ett antal år framåt. Flera av de tingsrätter som ganska nyligen har lagts ned eller kommer att läggas ned inom kort ansågs redan på 1960-talet vara alldeles för små för att ens överleva 1971 års reform. Detta ger en klar indikation på att statsmakten länge intog en nästan anmärkningsvärt försiktig hållning i fråga om förändringar av underrätternas yttre organisation.

Synen på förändringarna av underrätterna har i viss mån varit en vänster-höger-fråga i politiken, där vänsterblocket har varit mer benäget än de borgerliga att slå samman tingsrätter i ganska snabb takt. Dessa skiljelinjer är inte särskilt förvånande. De borgerliga partierna, särskilt moderaterna, har av tradition haft en högre profil i rättsfrågor än vad som har varit fallet med Socialdemokraterna och deras två stödpartier. När frågan ses utifrån ett centraliserings- och decentraliseringsperspektiv ligger det också mycket nära till hands att centerpartiet av lång tradition agerar mot vad som partiet uppfattar som alltför långtgående indragningar av tingsrätter i landsorten.

När förändringarna av underrätterna ställs i relation till de omdaningar som har skett inom andra rättsvårdande myndigheter i samhället, främst polisen och åklagarväsendet, ter sig dock inte ens dagens förändringar som anmärkningsvärt stora. Polis- och åklagarväsendet har i två steg genomgått omfattande centraliseringsprocesser i mer modern tid. Den första var 1965 då polisväsendet i sin helhet förstatligades och det gjordes en tydlig åtskillnad mellan polis, åklagare och kronofogdemyndighet även på landsbygden. Antalet polisdistrikt minskade vid denna tidpunkt från 562 till 119. Detta innebar också att antalet polisstationer reducerades från knappt 1000 till drygt 500. Under senare delen av 1990-talet skedde nästa centraliseringsprocess, då antalet polismyndigheter reducerades till en i varje län, i nuläget alltså 21 stycken. Åklagarväsendet har också genom en regionalisering genomgått en ytterligare centralisering under mitten av 1990talet.[26] Rimligen borde allmänheten ha betydligt högre krav på polisens geografiska tillgänglighet, inte minst i samband med olika former av brådskande ärenden, än vad som är fallet med underrätterna. 
Vid en värdering av för- och nackdelar med dagens sammanslagningar av tingsrätter kan det konstateras att för domstolarnas professionella kompetens bör en mer storskalig struktur vara en fördel. Den personella sårbarheten i de minsta tingsrätterna är ett annat bekymmer som det är svårt att bortse från. Om tingsrätterna lokaliseras till orter där åklagare och häkten finns placerade underlättas också samarbetet mellan myndigheterna inom rättsväsendet. För polisens del finns det uppenbarligen både fördelar och nackdelar med färre tingsrätter. Fördelarna sammanfaller i stora drag med vad som gäller för åklagare och häkten, medan nackdelarna uppkommer när poliser skall inställa sig vid rättegångar och i samband med polishämtning av personer som skall ställas inför rätta eller vittna. För rättsväsendets interna effektivitet som helhet får det anses sannolikt att fördelarna trots allt klart överväger nackdelarna.

Rättsväsendet är dock inte minst till för medborgarna. Utifrån ett medborgarperspektiv är reformen något mer diskutabel. Även om det i dagens urbaniserade samhälle finns goda allmänna kommunikationer i kombination med en väl utbyggd privatbilism är ändå de längre geografiska avstånden negativa för allmänhetens tillgänglighet till domstolarna. Den geografiska tillgängligheten kan dock förbättras genom att avvecklade tingsrätter behålls som tingsställen. Mot detta kan anföras att det stora flertalet medborgare sällan eller aldrig kommer i direkt kontakt med tingsrättsförhandlingar. Det bör finnas andra former av offentlig service såsom olika former av kommunal verksamhet och sjukvården där behovet av geografisk tillgänglighet är större än i fråga om domstolarna. Det är fullt tänkbart att allmänhetens relativt begränsade protester mot dagens nedläggningar av tingsrätter skall ses som ett uttryck för att neddragningar av annan offentlig service, exempelvis inom akutsjukvården, ses som mer allvarliga och känslomässigt engagerande Det skall särskilt noteras att under senare år har ett flertal landsting (regioner) gjort avsevärda centraliseringar av akutsjukvården. Detta har i många fall medfört utbredda protester hos lokalbefolkningen på de berörda orterna.

Som kommunhistorisk forskare gör jag kopplingar till de sammanläggningar av kommuner som skedde i stor skala i två etapper under perioden 1952-1974, då antalet kommuner minskade från 2498 till 278. I jämförelse med dessa sammanläggningar har domstolarna kommit relativt lindrigt undan, även om framtida sammanläggningar, vilka leder till en organisation med mellan 30-40 tingsrätter, beaktas. I fråga om demokratiska aspekter och tillgång på service får tämligen långtgående kommunsammanläggningar, enligt min bestämda uppfattning, långt större konsekvenser för medborgarna än dagens nedläggningar av tingsrätter. En annan betydelsefull skillnad är att domstolarna är statens eget ansvarsområde, medan kommunerna är lokala folkvalda organ som skall utöva ett visst mått av självstyre.

Samtidigt finns det en tämligen begränsad grupp medborgare som aktivt deltar i domstolarnas verksamhet som lekmän, nämligen nämndemännen. Redan tidigare har det framhållits att nämndemännen inte är representativa för befolkningen i stort. En del i detta är nämndemännens höga medelålder.[27] Genom de betydligt längre geografiska avstånden till tingsrätterna i framtiden kan det, enligt mitt förmenande, snarast bli svårare att åstadkomma någon förbättring av nämndemännens representativitet. Risken för att nämndemännen till alltför stor del består av människor som inte längre är förvärvsarbetande kan inte alls uteslutas när tingsrätten är belägen på många mils avstånd från hemkommunen. Det skall emellertid betonas att även med den mer decentraliserade tingsrättsorganisation som gällde fram till 1999 visade det sig vara ganska svårt att komma till rätta med snedrekryteringen av nämndemän. Det kan därför knappast anses vara rimligt att avstå från sammanläggningar av tingsrätter enbart av hänsyn till rekryteringen av nämndemän.

\section{(C) Erik Wångmar}

[1] Sven Ulric Palme, "Kommunerna i den fulla demokratins samhälle", i Hundra år under kommunalförfattningarna. Stockholm 1962, s 277f, Bengt Svensson, "Kommunerna i den 
tidiga industrialismens samhälle", i Hundra år under kommunalförfattningarna. Stockholm 1962, s 89ff, Göran Inger, Svensk rättshistoria, Lund 1980, s 166ff, Lars Nilsson, Den urbana transitionen. Tätorterna i svensk samhällsomvandling 1800-1980, Stockholm, 1989, s 9 och 128ff samt Lars Nilsson, Historisk tätortsstatistik. Del 1: Folkmängden i administrativa tätorter 1800-1970, Stockholm, 1992 s 15, 23, 44 och 61.

[2] Jan Erik Almquist, Lagsagor och domsagor i Sverige. Med särskild hänsyn till den judiciella indelningen, del 1 Stockholm 1955, Anders Bruzelius, Rättskunskap. I

Rättsreglerna, Lund 1965, s 177ff, Jan Erik Almquist, Svensk rättshistoria. I

Processrättens historia, Stockholm 1975, s 13f, Sveriges Statskalender 1901 s $88 \mathrm{ff}$ och 228-248, SOU 1961:6, Underrätterna. Betänkande avgivet av stadsdomstolsutredningen s 15ff och SOU 1967:4, Domstolsväsendet: betänkande 2, Ny domkretsindelning för underrätterna. Betänkande avgivet av Domstolskommittén.

[3] Sveriges Statskalender 1901-1970, SOU 1961:6 och SOU 1967:4.

[4] SOU 1961:6, SOU 1963:56, Domstolsväsendet: I Rådhusrätternas förstatligande. Betänkande avgivet av domstolskommittén, s 104, Almquist 1975, s 16, och Sveriges Statskalender 1901-1970.

[5] Bengt Järbe, Polisen i Stockholm förr och nu, Stockholm 1975, s 119ff och 153ff, Jan Eric Almqvist 1975, s 18f, Göran Inger 1979 s 296ff, Carl Persson, Utan omsvep. Ett liv i maktens centrum, Stockholm 1990, s 76ff, och Erik Anners, Brottet, straffet och polisen i den europeiska rättsutvecklingen, Stockholm 1997, s 188.

[6] Sveriges Statskalender 1901-1970, SOU 1963:56, s 102, och Jan Erik Almquist 1955.

[7] SOU 1961:6, SOU 1963:56, SOU 1967:4, Kjell Å Modéer, Historiska Rättskällor. En introduktion i rättshistoria, Stockholm 1993, s 178, och Jonas Nordquist, Domstolar i det svenska politiska systemet. Om demokrati, juridik och politik under 1900-talet (diss),

Stockholm 2001, s 85ff.

[8] SOU 1967:4.

[9] Proposition 1969:44.

[10] Utlåtande första lagutskottet $1969 \mathrm{nr} 38$, protokoll första kammaren 1969 nr 29 s 3258 och protokoll andra kammaren $1969 \mathrm{nr} 29$ s 42-69.

[11] Sveriges Statskalender 1971 s 301-316.

[12] Erik Wångmar, Från sockenkommun till storkommun. En analys av storkommunreformens genomförande 1939-1952 i en nationell och lokal kontext, Växjö 2003, s 221ff.

[13] Sveriges Statskalender 1971-1977 och SFS 1973:740.

[14] Sveriges Statskalender 1971-1999, SFS 1974:735, 1975:1284, 1976:904, 1979:961, 1982:995 och 1982:996 samt SOU 2003:5, Förändringar i tingsrättsorganisationen - en utvärdering av sammanläggningar av tingsrätter 1999-2001.

[15] Ds 1992:38, Domstolsväsendet. Organisation och administration i framtiden, SOU 1998:135, Domstolsorganisationen — sammanställning från 1995 års domstolskommitté, s 28 och SOU 2003:5 s 16f.

[16] Kommittédirektiv Justitiedepartementet 1998:22, SOU 1998:135 s 108ff, och SOU 2003:5 s 17.

[17] Regeringens skrivelse 1999/2000:106.

[18] Betänkande justitieutskottet 1999/2000:22 och Peter Fitger och Mikael Mellqvist, Domstolsprocessen. En kommentar till rättegångsbalken, Stockholm 2002, s 15.

[19] Regeringens skrivelse 2000/2001:112.

[20] Betänkande justitieutskottet 2000/2001:29 och protokoll riksdagen 2000/2001:125 s 4.

[21] SOU 2003:5.

[22] Regeringens skrivelse 2002/2003:126.

[23] Proposition 2003/2004:1 Bilaga 25 s 109ff.

[24] Betänkande justitieutskottet 2003/2004:4 och protokoll riksdagen 2003/2004:26.

[25] Hanns von Hofer, "Sverige - ett land i civilisatoriskt förfall? Svensk brottslighet jämförd med andra länders", i Brott och straff: en antologi, Stockholm 2000, s 27-36, Eva Österberg, "Brott, straff och brottsoffer i ett historiskt perspektiv", i Brott och straff: en antologi, Stockholm 2000, s 78-91, Lars Westfelt, "Utvecklingen av registrerade brott under efterkrigstiden. Sverige i europeisk belysning", i Brottsligheten i Europa, (red) Hanns von Hofer, Stockholm 1998, s 20-37, Thomas Ekbom, Gunnar Engström och 
Birgitta Göransson, Människan, brottet och följderna. Kriminalitet och kriminalvård i Sverige, Stockholm 2002, s 13-24 och 237ff.

[26] Curt Falkenstam, Polisernas krig, Stockholm 1983, s 28ff, Persson 1990 s 76-87, Thomas Ekbom, Gunnar Engström och Birgitta Göransson, 2002, s 113f, SOU 1998:135 s 57 och Sveriges Statskalender 1994-2000. I fråga om antalet polisdistrikt direkt före förstatligandet anges både siffrorna 562 och 554.

[27] SOU 2002:61, Framtidens nämndemän. Betänkande av Nämndemannakommittén, s $61 \mathrm{ff}$. 